\title{
Australia and the Indonesian Independence
}

\author{
Sah-Hadiyatan Ismail \\ School of Distance Education, Universiti Sains Malaysia \\ 11800 Penang, Malaysia \\ Tel: 60-4-653-2279 E-mail: sah.ismail@usm.my
}

Received: October 17, $2010 \quad$ Accepted: November 10, 2010 doi:10.5539/ass.v7n5p151

\begin{abstract}
Immediately after World War II, the Indonesian nationalists declared the independence of Indonesia and staunchly opposed the return of the Dutch to the Netherlands East Indies. The Australian Labor government took the position to support the Indonesian nationalist instead of the Dutch. This position was taken based on the rights of self-government for the dependent peoples enshrined in the United Nations Charter and championed by Australia. Besides Australia's idealism on the colonial issue, the concern for political development in Indonesia was also based on the growing awareness of the consequences this issue might pose to Australian security. Australia's support for Indonesia put Australia in a different position with the United States and Britain as both countries supported the Dutch. Australia worked hard to settle the 'crisis' in Indonesia and brought the Indonesian-Dutch disputes to the United Nations Security Council even it against the US advise. The period of August 1945 to October 1949 clearly showed that Australia's independence in making decision on its foreign policy away from the influence of the American and British policy in Southeast Asia. The short-lived independence in foreign policy was overturned in late 1949 with the formation of the new Australian government by the Liberal-Country Party.
\end{abstract}

Keywords: Indonesia, Australia foreign policy, Independence

\section{Introduction}

World War II and the decolonisation process that followed changed Australian perceptions about its immediate surroundings tremendously and Australia began to display an increasing interest in Asia. In Southeast Asia, the end of World War II saw the emergence of nationalism, communism, and anti-colonialism that created instability, especially in Indonesia, Indochina and Malaya. Australia acknowledged this situation and believed that World War II brought the peoples of Southeast Asia an opportunity of political development at a rate previously never been experienced by them. Evatt clarified the growing Australian concern of this situation and believed that "as the peoples of South East Asia cease to be dependent upon the decisions of European Governments, so far do Australia's interests in the councils of South East Asia increase". (Note 1) The Australian government realised much more strongly the importance of its neighbours to the North, the need to establish personal contacts with Asian leaders and to study Asian problems. Besides this, Australia has to accept that the Western powers were no longer a dominant power in Southeast Asia.

This article focuses on the general development of Australian foreign policy towards Indonesia. It is important as the declaration of the independence of Indonesia in August 1945 signified Australia's relationship with a newly independent Asian country. The conduct of Australian foreign policy became an important issue in Australian politics especially after the appointment of Australia to the United Nations Security Council in early 1946. In this period of time, it is very clear that Australia was trying to find a new approach in its own foreign policy. Australia now had to forge direct relations with the newly independent nations in Southeast Asia rather than dealing with the European colonial masters as was the case before World War II. Australia wanted to have a good relationship with countries in Southeast Asia to expand its trade as it believed Southeast Asia would be a good customer for the Australian products. A good relationship with Southeast Asia was also important to the defence of Australia.

\section{The Early Involvement}

Australia was interested in the struggle between the emerging Republic of Indonesia and the returning Dutch. Australia considered its relations with Indonesia as very important because it was its nearest neighbour. Indonesia had a very big population and potentially rich with natural resources but not politically stable because of anti-colonial revolution in August 1945. 
Until World War II, Indonesia was known as the Netherlands East Indies (NEI) and was ruled by the Dutch. During World War II, Australia had been host to Dutch forces and the NEI administration-in-exile from March 1942. Australian troops were part of the British forces which liberated parts of Indonesia from Japanese occupation and restored the Dutch administration. In May 1945, before the surrender of the Japanese, the Australian $9^{\text {th }}$ Division captured the oilfields on Tarakan Island, off the north east coast of Borneo. By the end of the war, there were more than 50 thousands Australian troops in the Netherlands East Indies. By agreement with the Allied forces, "Australia was assigned with post war tasks such as accepting the surrender of Japanese forces, repatriating them, freeing Allied prisoners of war and internees, and restoring law and order until the Dutch Netherlands East Indies government resumed formal control". (Lee, 2001:141) These military actions by Australian forces in liberating the NEI later became the basis for the Australian government's involvement with other European powers in the later stage of the reoccupation of the NEI.

In the NEI on 17 August 1945, just two days after the Japanese surrender, Sukarno, the Indonesian nationalist leader, proclaimed Indonesian independence at a simple ceremony in Jakarta. The nationalist leaders then moved quickly to assert their authority and to establish the foundations of a new republic before the arrival of Allied forces. The Australian government was surprised to learn about the declaration of Indonesian independence "in a shortwave radio broadcast from Batavia [Jakarta] on 19 August". (Note 2)

The Dutch attempting to re-establish their authority in the NEI, labelled Sukarno and Hatta as collaborators with the Japanese and the Republic of Indonesia as a creation of Japanese fascism. (Note 3) The Republicans fiercely resisted the Dutch claim to establish authority in Indonesia. British Allied forces who were reoccupying the NEI on behalf of the Dutch were also attacked by the Republicans in Surabaya on 28 October. The British then pressed the Dutch to negotiate with the Republicans. The Dutch initially refused to negotiate with the Republicans and acceded to British pressures only after fighting of shocking intensity in Surabaya and the lack of Dutch military strength.

The conflict between the Dutch and the Republicans was not confined to the NEI only. Indonesian Independence Committees and a Central Committee of Indonesian Independence (CENKIM) were established in Brisbane shortly after the declaration of Indonesian independence. On 1 September 1945, CENKIM announced in a manifesto that "a reimposition of the undemocratic and ruthless Dutch rule over the peoples of Indonesia is not and never will be accepted by our people". (Lockwood, 1982:93) This manifesto also called for all Australians and Indonesians to give assistance in the Indonesian struggle to win basic rights. The response to this call was overwhelming as on 22-23 September Indonesian merchant seamen in Brisbane, Sydney and Melbourne "walked off" Dutch ships which were being loaded with supplies for the Dutch reoccupation of Netherlands East Indies. On 24 September the Australian waterside workers imposed a black ban on the loading in all Australian ports of Dutch ships destined for the Netherlands East Indies.

On 7 November 1945, the first Australian representative to visit the NEI after the Japanese surrender, W. McMahon Ball, arrived in Jakarta. Ball was directed by the Department of External Affairs to investigate the situation in NEI and to ascertain "how far the Republic was a genuine nationalist movement and to assess the calibre of the Republican leaders". (Dorling, 1994: xii) British representatives in Jakarta were "unenthusiastic" toward the Australian initiatives and tried to interpret Ball's status as an "independent political representative" from Australia. (George, 1980) Britain was not interested in supporting Australian efforts in achieving a political solution of the Dutch-Indonesian situation because that conflicted with Britain's priority for its own disengagement from the Netherlands East Indies. Australia's interest in a Dutch-Indonesian political solution derived from the Australian viewpoint that put Indonesia and Southeast Asia as an integral part of its future defence and military security. However, Britain did not share Australia's enthusiasm for a settlement in favour of Indonesian Republicans as British views on the settlement of the conflict between the Dutch and the Republican were influenced by many factors, such as its own position as a colonial power in Malaya, Borneo, and India. Britain was also interested in having good relations with the Netherlands, a neighbour in Europe. With these factors, the British view on the settlement of problems in the NEI was different from that of Australia. When it failed to influence Britain, Australia considered the alternative of appealing to the United States to sponsor a solution to the NEI conflict. Australia knew that it could not do much without the influence from big powers such as the Americans and British. The Australian government's attitude of going to one big power after another was for its own benefit as it wanted the problems in NEI its closest neighbours to be settled according to its view.

\section{The Linggarjati Agreement}

Evatt publicly expressed the Australian government's support for the self-government of the Indonesian peoples in March 1946. (George, 1980) The Chifley government "deliberately dissociated Australia from the major Western 
bloc" by supporting the Indonesian Republic in its dispute with the Dutch as Australia perceived the British and American support for the Dutch was influenced by the sympathy for fellow colonial power in Southeast Asia. (George, 1980) On 12 March 1947 the Australian government explored the possibility with the United States of raising the Indonesian situation with the Security Council of the United Nations. Alfred Stirling, Minister at the Australian Embassy in Washington, had discussions with John H. Morgan of the Division of Northern European Affairs and William S. B. Lacy of the Division of Southeast Asian Affairs in the Department of State, on the Indonesian question and the Australian plan to raise the issue at the Security Council. Lacy and Morgan informed Stirling that based on the approval of the Cheribon Agreement [Linggarjati agreement] by the Indonesian Central National Committee and in view of the US understanding that the Dutch government had an optimistic view of the possibility of early ratification of the agreement, the United States was reluctant to take new action to solve the conflict. (Note 4) However, the US would appreciate any information from the Australian government regarding the situation in Indonesia, and should the situation deteriorate, the US would consider the proposals for a peaceful solution suggested by the Australian government. (Note 5)

In April 1947, the Acting Secretary of State Dean Acheson instructed the Consulate General in Batavia [Jakarta] to inform the Governor General of the Dutch East Indies, H. J. Van Mook, and Republican Prime Minister Sutan Sjahrir in writing "that the US recognizes de facto jurisdiction of Republic of Indonesia in Sumatra, Java and Madoera". (Note 6) The US also hoped that both the Dutch and the Republican governments would negotiate the implementation of the resolution outlined in the Linggarjati Agreement. Two weeks later, the Dutch Ambassador to the Soviet Union, A.H.J Lovink, met with Secretary of State George Marshall in Moscow and emphasised the need for Western power cooperation "in the Social, Economic, and Cultural fields with the accent on the necessary work of reconstruction" in Southeast Asia. The Dutch approach to the US was based on the intention to avoid the weaker Asian countries, including the NEI, from falling "to a Pan-Asiatic alliance under the aegis of India or China". The Americans, although in favour of "some degree of cooperation among Democratic Powers concerned in the Far East", did not make any commitment on the necessity for formalizing this effort. (Note 7) The US disagreed with the Dutch on the alleged Communists influence in the NEI and hoped to eliminate the conditions which have made Communists influence attractive. Any joint Western powers approach to the Indonesian leaders must be done carefully in order not to "be interpreted by the Indonesian as a threat to their national aspirations" and defeating the purpose of stabilising the present Indonesian government. The Dutch then took the opportunity to emphasise the ties between Indonesian Communists and Communists organizations in Singapore and China. The Dutch believed that "the strategic stake for Moscow is high - a Communist stronghold situated between Singapore, the Philippines and Australia". Secretary Marshall felt that the present Communists influence in Indonesia was "neither widespread nor effective". The Americans hoped to consolidate and strengthen the present Indonesian leadership which they believed to be "Socialist and not Communist, Nationalist and not Soviet-controlled". (Note 8) The United States then requested the Netherlands Foreign Office to inform the Indonesian Republic that "it accorded the Republic same de facto recognition" accorded by Netherlands Government under the Linggarjati Agreement. The Americans also recognized the sovereignty of the Netherlands in the NEI. The American Consul General in Batavia would continue to represent the Americans in the NEI and the US desired its Consul General "to deal directly with Indonesian authorities in matters determined to be within their competence." (Note 9)

After the Linggadjati Agreement that conferred on the Republic of Indonesia de facto authority over Java, Madura and Sumatra, the Australian Department of External Affairs (DEA) began to establish an Australian-Indonesian Commercial and Diplomatic (formal and informal) relationship between Australia and the Indonesian Republican government. The Minister of External Affairs had been urged by his advisors to appoint a personal representative of the Minister, as well as an expert on trade, for a mission to Indonesia. (Dorling, 1994) This mission is hoped establish close contact with Republican Prime Minister Sutan Sjahrir and his Ministers. The DEA also suggested that a loan of $£ 25$ million with conditions that might include employment of Australian advisers and technicians be offered to the Republic in order to strengthen Sjahrir's position. Chifley also acknowledged the economic importance of Indonesia and the possibility of increased trade as he mentioned that "70,000,000 Indonesians might be [a] very good customer ... this country would be as likely to get trade from the Indonesians as from the Dutch". (Lee, 2001:152) The discussions regarding financial loans to Indonesia and the possibility of trade demonstrates that as well as for security and defence reasons, the involvement of the Australian government was grounded in economic matters.

In the middle of 1947, Britain and the United States refocussed their attention on the failure of the Netherlands and the Indonesian Republic to reach a peaceful compromise settlement. Both countries had capital investments in the NEI and they hoped for economic normalization and the restoration of NEI external trade. The US and Britain also feared the Dutch would take military action against the Republic, and strongly urged the Netherlands to seek a 
negotiated settlement with the Republic, and for the Republic to accept the Dutch proposals. On 11 June 1947 the Dutch informed the United States that they might take military action against the Republic. The United States then independently appealed to the two parties to seek peaceful co-operation and, on 25 June, the United States urged the Dutch and the Republicans to co-operate in forming an interim government. Following this, the Australian government on 26 June offered its "good offices" to the Dutch and the Republic to assist in forming that interim government as suggested by the United States the day before. The Australian offer, however, was preceded by similar offers by Britain and the United States. This led the Dutch to regard the Australian offer as "reflecting Evatt's desire to intervene in the NEI dispute and as a deliberate attempt by Australia to compete with the British and United States offer". (George, 1980:79) The suggestion of Dutch and Republicans cooperating in an interim government did not materialise as Republican Prime Minister Sjahrir was facing with serious domestic opposition for having yielded so much already to Dutch demands. On 27 June, Sjahrir resigned his premiership of the Republic.

On 9 July, Australia announced its recognition of the de facto status of the Indonesian Republic and renewed its offer of assistance and advice to both the Republican government and the Dutch. The Dutch again refused the offer of such help from Australia and considered the Australian offer as "source of annoyance" to the Netherlands government. The Dutch government instructed its Minister in Canberra to inform Evatt that the "Netherlands Government does not consider the moment chosen by him to proffer good offices either timely or helpful". (Note 10) The Dutch refusal and resistance to any Australian offer for help was predictable as the Dutch were annoyed by what they construed as constant Australia support for the Indonesian Republic.

\section{To the United Nation}

The Dutch launched its first 'police action' against the Republic in July 1947 after Dutch-Republican co-operation broke down. The Republicans sought help from Australia and pressed the Australian government to take action and intervene in the dispute. Australia cautiously explored the views of other Western powers before taking any action. Britain informed Australia on 23 July that "it would not wish to interfere with whatever action Australia might decide to take" to end the dispute. Britain then proposed to the United States that the US and Britain "jointly offer to arbitrate the dispute in order to pre-empt its possible referral to the United Nations by some other power". The US also warned Australia of the "delays and frustrations which Security Council intervention would involve" and hoped that Australia would not refer the dispute to the UN. (George, 1980:82) Against the advice from the US, on 30 July, Australia and India brought the matter to the attention of the Security Council under Chapter VII of the Charter. Australia asked the Security Council to determine the existence of a breach of the peace (Article 39). Australia also submitted a draft resolution calling for the "immediate end to hostilities and for the parties to submit their dispute to arbitration in the terms of Article 17 of the Linggadjati Agreement". (George, 1980:84) Australia's action was predictable, although against US advice as it had explored the possibility of bringing the Indonesian question to the UN since March 1947. Australia's action of going against the US advice was a proof of its independent foreign policy that did not subscribe to the American wishes in period of 1946-1948.

The United States then offered its "good offices" to both the Dutch and the Indonesian Republicans as a counter-move to Security Council intervention, arguing against the terms of the Australian resolution at the Security Council. The US delegates also challenged the Australian arguments and Australia had to overcome the difference of opinion as to the jurisdiction of the Security Council. Australia then had to accept the Security Council decision for an alternative resolution that had been submitted by the United States which omitted reference to Articles 39 and 40 of the Charter. The resolution submitted by the US was adopted on 1 August and read:

The Security Council, noting with concern the hostilities in progress between the armed forces of the Netherlands and the Republic of Indonesia, calls upon the parties:

a. to cease hostilities forthwith; and

b. to settle their disputes by arbitration or other peaceful means and keep the Security Council informed about the progress of the settlement. (Note 11)

The United Nations Security Council then established a Good Offices Committee to sponsor further negotiations between the Dutch and the Indonesian. Australia was nominated by the Indonesian Republican government as its representative on the United Nations' Good Offices Committee on 8 September 1947. The negotiations under the Security Council Good Offices Committee led to the Renville Agreement, which was ratified by both sides on 17 January 1948. Australia played an important part in the work of the Good Office Committee and in the negotiations leading to Indonesia's formal independence in December 1949. The nomination of Australia showed the official confidence of the Indonesian Republic in Australian influence. Once the Dutch-Indonesian conflict was submitted 
to the Security Council for resolution, the Australian government recognized the importance of winning the United States' endorsement of its viewpoint and of seeking United States co-operation to resolve the conflict. Although Australia recognised the importance of winning the Americans' endorsement on its view, Australia strangely took a position that was contrary to the Americans. Australian-American co-operation regarding the Dutch-Indonesian conflict in 1947-1949 was minimal as Australia was not confident of US support for the Republic. There was considerable conflict between Australia and the United States as "Australia strove to give the UN Good Offices Committee arbitral as well as mediatory powers in Indonesia". The Americans noted that Evatt had abandoned his previously pro US and Britain position on major policy matters in favour of "the more neutral role of mediator." (Note 12) The United States prior to the 1948 Madiun Affair was suspicious of the Indonesian Republican leaders stand towards Communists elements in Indonesia. (Note 13) The Americans began to see the Republicans as anti-Communists after the Madiun Affair and began to pressure the Dutch to accommodate the Republic's independence demands. (Note 14)

\section{Reversal}

Australia's relations with Indonesia took a different turn by the end of 1949. The Liberal-Country Party (LCP) coalition won the Australian election and the new government under Robert Menzies was less sympathetic to the ideology and aspirations of the Indonesian Republican leaders than the previous government under Ben Chifley. The Menzies government's attitude towards the Indonesian Republican leaders was influenced by the overall world situation in late 1949, notably the 'fall' of China to the Communists and the intensification of the Cold War in Europe. Menzies and most of his Western counterparts were suspicious of Asian leaders like Sukarno and their attitudes towards the Communists. These Western governments believed that the Communists might influence and capture the leadership of the nationalist organisations leading the Communists into power in these newly independent Asian countries.

The Menzies government's attitude towards Indonesia and its suspicion of Indonesian leaders worsened when Indonesia began actively to seek to secure sovereignty over the territory of West New Guinea. The issue of West New Guinea then became a threat to relations between Australia and Indonesia. The West New Guinea territory had been under Dutch administration as part of the East Indies until its defeat by the Japanese in March 1942. The Dutch refused to hand over West New Guinea as part of Indonesia at the time of the transfer of sovereignty in late 1949, while the Indonesian government claimed West New Guinea as part of its territory. The Australian government did not oppose the Dutch attitude because Indonesian possession of West New Guinea would raise "strategic problems for Australia". (Millar, 1978:48) Australia believed Indonesian sovereignty over West New Guinea would bring problems for Australia's defence. This was especially the case if Indonesia became hostile towards Australia. The Australian government felt that if the Dutch presence were completely removed from the Indonesian area, the Indonesian peoples might turn "their aggressive feelings from the Dutch as their white colonial master to Australia as their contiguous white, Western neighbour". (George, 1980:161) The assumption that Indonesia would threaten Australia after the departure of the Dutch was also held by the previous Chifley Labor government. Chifley tried to avoid this generalisation by the Asian countries by establishing Australian identity as a regional power which stressed that Australia was different from European colonial powers in Southeast Asia as mentioned earlier. This was also one the reasons the Australian Labor government gave its support to the Indonesian Republicans in their effort to gain independence from the Dutch.

The Australian LCP government believed that in reality the Indonesian government was less stable than the Dutch administration in the Netherlands East Indies. (Millar, 1978) The Australians believed that Dutch New Guinea should not be controlled or handed to a hostile or potentially hostile power as this would jeopardise the defence of Australian New Guinea and even island chains such as the Solomons and the New Hebrides. The experience of World War II where the islands in the north of Australia were used as a launching pad by the Japanese to attack Australia increased Australian interests in "the welfare and system of control" of these islands in order to prevent them from falling into the hands of unfriendly powers. From the Australian government's point of view, these islands were "within the extended Australian zone", especially in defence, trade, and transport matters. Australia was interested in seeing these islands being developed as "an asset in the defence of the South-West and South Pacific." (Evatt, 1945:142)

The Australian Labor government's foreign policy regarding the Dutch-Indonesia dispute was bold and radical and was only minimally influenced by American foreign policy. The Australians were at odd with the Americans as the Americans were much more sympathetic towards the Dutch. Australia's involvement and contributions in resolving this crisis was considered by the Australian government as an investment to strengthen its security by 
creating a "buffer state" that was friendly to Australia. The Australian Labor government wanted to make a good start with the Indonesians by helping them to gain their independence and supporting them in their dispute with the Dutch.

\section{Conclusion}

The policy to support the Indonesians in July 1947 was one of the 'independent' decisions made by the Australian government as the United States decided to support the Republic only late in 1948. This was a period of quasi-independence in Australian foreign policy and it had been acknowledged by the Americans in their assessment in August 1948.

During the period of 1947-1948, the Americans realised that Australia was anxious to avoid appearing as subordinate to Britain or the United States in its foreign policy. Australia chose to build up its own image and identity as a regional power and to differentiate itself from the European colonial powers in Southeast Asia. Australia believed with its geographic position and its growing responsibility for the defence of its own area that it should make a contribution to peace and the settlement of conflict in the Southeast Asian region. The Australian government considered its relations with Indonesia as an important aspect in its security. The Indonesian archipelago was seen by the Australian government as a buffer from a potentially aggressive Asian mainland.

Australia's support for the Indonesian Republic was based on its own assessment and estimates on the situation in Indonesia conducted by Australian officers as early as November 1945. Both Australian allies, Britain and the US, chose in the first instance to support the Dutch. Australia's support was also based on the idea that the Indonesian people should be given a chance to obtain the status of self-government and self-determination as enshrined in the United Nations charter. It would be an 'incompatible policy' for the Australian Labor government to support the United Nations Charter and at the same time to support the Dutch colonial power in oppressing Indonesian nationalism. The Australian government then put high hopes that the United Nation would be able to solve the conflict in Indonesia following the Dutch police action in 1947. The Australian delegates' strong support for Indonesia resulted in Australia being on a different side than to Britain and the United States. Australia chose to vote in support of Indonesia whereas both Britain and the US chose to be on the Dutch side until late 1948.

Apart from the security and strategic planning issues, Australia's support for the Republic was also based on its economic interests. From the early days of the Republic the Department of External Affairs suggested that Australia extend loans and assistance to strengthen the Republican government and looked for possibilities to place Australian advisors and technical teams in Indonesia. With its huge population, Indonesia, it was hoped, would be an important trade partner for Australia and a big market for Australian products.

The Australian government strong support for the Indonesian revolutionary leaders from August 1945 through October 1949 led Australia to be known as the 'mid-wife' in the birth of Indonesia. Australia was even chosen by these Indonesian leaders as a member in the United Nations Good Office Committee. However, the independent measures in foreign policy pursued by the Labor government were slowly dismantled and finally abandoned by the subsequent Liberal and Country Party government that came to power by the end of 1949 .

\section{References}

[Online] Available: http://countrystudies.us/indonesia/16.htm assessed 23 December 2008.

A3300 (A3300/7) 529, [1947 File-White Tab] Foreign Statements by Prime Minister, Dr. Evatt, etc, National Archives of Australia, Canberra, Australia.

Department of State. (1972). Foreign Relations of the United States1947, vol. VI. Washington: US Govt. Printing Office.

(1974). Foreign Relations of the United States 1948, vol. VI. Washington: US Govt. Printing Office.

Dorling, Philip (ed). (1994). Diplomasi Australia and Indonesia's Independence. Canberra: Australian Government Publishing Service.

Evatt, H.V. (1945). Foreign Policy of Australia: Selected Speeches from November 1941 to February 1945. Sydney: Angus \& Robertson.

George, Margaret. (1980). Australia and the Indonesian Revolution. Melbourne: Melbourne University Press.

Lee, David. (2001). Indonesia's Independence, In Goldsworthy, David (ed). Facing North. Carlton South: Melbourne University Press.

Lockwood, Rupert. (1982). Black Armada. Sydney: Hale and Iremonger. 
Millar, T.B. (1978). Australia in Peace and War. Canberra: The Australian National University Press.

Sah-Hadiyatan Ismail. (2010). The American Connection and Australian Foreign Policy in Southeast Asia, 1945-1965, Unpublished PhD thesis. University of Queensland, St. Lucia, Australia.

\section{Notes}

Note 1. Ministerial Statement, Together With Related Documents Tabled By Minister For External Affairs on the $26^{\text {th }}$ February 1947 in A3300 (A3300/7) 529, [1947 File-White Tab] Foreign Statements by Prime Minister, Dr. Evatt, etc, NAA.

Note 2. M.P. Schneider, Australia and Indonesian Independence: A Study in Australian Foreign Policy (B.A. Honours thesis, Adelaide, 1955), p. 12 quoted in Margaret George, Australia and the Indonesian Revolution (Melbourne: Melbourne University Press, 1980), p. 35

Note 3. http://countrystudies.us/indonesia/16.htm assessed 23 December 2008. This website contains the online versions of books previously published in hard copy by the Federal Research Division of the Library of Congress as part of the Country Studies/Area Handbook Series sponsored by the U.S. Department of the Army between 1986 and 1998.

Note 4. The Cheribon Agreement was also known as the Linggarjati Agreement and this thesis will use the term Linggarjati Agreement hereafter. In the Linggarjati Agreement, the Dutch recognized the Republic of Indonesia as de facto authority over Java, Madura and Sumatra. The areas occupied by Allied or Netherlands forces were to be included gradually, through mutual co-operation, into Republican territory.

Note 5. Memorandum of Conversation, by the Acting Assistant Chief of the Division of Southeastern Asian Affairs (Lacy), Washington 12 March 1947, FRUS 1947, vol. VI, p. 903.

Note 6. The Acting Secretary of State to the Consulate General at Batavia, Washington, 3 April 1947, FRUS 1947, vol. VI, (Washington: US Government. Printing Office, 1972), p. 912.

Note 7. Memorandum by the Chief of the Division of Northern European Affairs (Cumming) and the Chief of the Division of Southeast Asian Affairs (Moffat), Washington 17 April 1947, FRUS 1947, vol VI, pp. 917.

Note 8. Memorandum by the Chief of the Division of Northern European Affairs (Cumming) and the Chief of the Division of Southeast Asian Affairs (Moffat), Washington 17 April 1947, FRUS 1947, vol VI, pp. 918.

Note 9. The Acting Secretary of State to the Embassy in the Netherlands, Washington, 24 April 1947, FRUS 1947, vol. VI, p. 919.

Note 10. The Charge in the Netherlands (Chapin) to the Secretary of State, The Hague, 10 July 1947, FRUS 1947, vol. VI, p. 976.

Note 11. Security Council, $2^{\text {nd }}$ Year, p. 1839, footnote 1, quoted in FRUS 1947, vol. VI, p. 1003.

Note 12. Policy Statement of the Department of State, Washington, 18 August 1948, FRUS 1948, vol. VI. p.2.

Note 13. The Madiun Affair originated with the leadership of the Indonesian Communist Party calling on the Indonesian people to overthrow the Republican government because of Republican compromises with the Dutch on Indonesian independence. Local clashes between Republican armed forces and the Indonesian Communist Party broke out in September 1948 in Surakarta. The Communists then retreated to Madiun and after some time were defeated by the Republican army.

Note 14. http://countrystudies.us/indonesia/16.htm (December 23, 2008). 